\title{
タラヨウの当年葉および古葉中のカフェ酸誘導体含量の 季節変動
}

\author{
翠川美穂*·亀山眞由美** ·永田忠博*
}

（"聖徳大学大学院， **独立行政法人 農業·食品産業技術総合研究機構 食品総合研究所）

\section{Seasonal difference of caffeic acid derivative contents in current-year leaves and old leaves of Ilex latifolia Thunb.}

\author{
Miho Midorikawa, Mayumi Ohnishi-Kameyama, Tadahiro Nagata
}

* Seitoku University Graduate School, 550, Iwase, Matsudo, Chiba, 271-8555

** National Food Research Institute, 2 - 1 -12, Kannon-dai, Tsukuba, Ibaraki, 305-8642

$$
\begin{gathered}
* \text { \% } 271-8555 \text { 千葉県松戸市岩瀬 } 550 \\
* * \text { \% 305-8642 茨城県つくば市観音台 } 2-1-12
\end{gathered}
$$

\begin{abstract}
We have determined 6 caffeic acid derivatives in order to study the seasonal differences of Ilex latifolia Thunb. leaves which are used to make Ku-ding cha in China. The current-year leaves (new ones) and old ones are obtained from male or female plants in the spring or autumn. Freeze-dried samples were extracted with $80 \%$ methanol and analyzed by HPLC. The leaves contain have no caffeine, but have some caffeic acid and 6 derivatives, including chlorogenic acid. The current-year spring leaves have high amounts of caffeic acid derivatives that range from $147 \sim 235 \mathrm{mg} / \mathrm{g}$ (dry weight), but the current-year autumn ones, old spring ones and old autumn ones have low amounts of are $36 \mathrm{mg} / \mathrm{g}(\mathrm{dw}), 24 \sim 44 \mathrm{mg} / \mathrm{g}(\mathrm{dw})$ and $31 \mathrm{mg} / \mathrm{g}(\mathrm{dw})$ respectively. 4-O-caffeoyl quinic acid in the current-year leaves increased 3 to 6 times from spring to autumn. No new leaves were collected from the female plant because they did not germinate. Therefore, the contents of the caffeic acid derivatives in the female plant were similar to those in the old leaves in the male plant. These results of the caffeic acid derivatives suggest that the new spring leaves of Ilex latifolia Thunb. are a good source for antioxidants.
\end{abstract}

\section{緒言}

タラョウ (Ilex latifolia Thunb.) は静岡県以西の本州, 四国，九州扮よび中国東部に分布するモチノキ科モチノ キ属の常緑高木で ${ }^{1)}$ ，原色樹木大圖鑑2)によれば，葉は 茶の代用とすると記されている。中国では, タラヨウを 含む10種類の植物から製造される苦味を持った健康茶を 総称して苦丁茶と呼び飲用されている ${ }^{3)}$ 。この苦味は, タラヨウ中のクロロゲン酸（5-O-カフェオイルキナ酸, 以下 5-CQA）を含むカフェ酸誘導体（Fig. 1) やトリ テルペノイドサポニンの存在 ${ }^{4)}$ －8)によると考えられて いる。カフェ酸誘導体は消臭効果, 抗変異原活性, 血糖 值改善効果を有すると報告されている ${ }^{4), 9) ~-11) ~ こ と か ら, ~}$
タラヨウを茶として飲用することで, これらの機能の発 現も期待できる。

モチノキ属の植物を茶として飲用する習慣は, タラヨ ウだけではない。わが国ではアオハダ (Ilex macropoda) の葉をコウボウ (弘法) 茶として飲用する地方がある ${ }^{1)} 。$ パラグアイ，ブラジルなどで飲用されるマテ茶は，モチ ノキ属植物であるマテ (Ilex paraguariensis) の乾燥葉を 浸出したもので, 抗酸化性や抗発がん性があるカフェ酸 誘導体やサポニンを多量に含むことが報告されている ～14)。なお，マテ茶にはカフェインが含まれるが15)，夕ラ ヨウは同じモチノキ属でもカフェインを含まないとされ ている ${ }^{16)}$ 。

タラヨウ中のカフエ酸誘導体に関する研究は少なく, 
<smiles>O=C(O)/C=C/c1ccc(O)c(O)c1</smiles>

caffeic acid<smiles>O=C(O)C1(O)CC(O)C([PH3+])C(O)C1O</smiles>

\begin{tabular}{lccc}
\hline & $\mathrm{R}_{1}$ & $\mathrm{R}_{2}$ & $\mathrm{R}_{3}$ \\
\hline 3-CQA & Caffeoyl & $\mathrm{H}$ & $\mathrm{H}$ \\
4-CQA & $\mathrm{H}$ & Caffeoyl & $\mathrm{H}$ \\
5-CQA & $\mathrm{H}$ & $\mathrm{H}$ & Caffeoyl
\end{tabular}

3,4-CQA Caffeoyl Caffeoyl Caffeoyl

3,5-CQA Caffeoyl H Caffeoyl

4,5-CQA H Caffeoyl Caffeoyl<smiles>CC(=O)/C=C/c1ccc(O)c(O)c1</smiles>

Fig. 1 Structures of the caffeic acid derivatives found in the Ilex latifolia

Table 1 Sampling for analysis of Ilex latifolia

\begin{tabular}{cccccc}
\hline name & sampling point & year & season & sex & leaf position \\
\hline \hline & & 2007 & spring & male & current-year \\
A & Botanical Gardens, Graduate School of & 2007 & spring & male & old \\
& Science, The University of Tokyo & 2008 & spring & male & current-year \\
& (Koishikawa Botanical Gardens) & 2008 & spring & male & old \\
\hline \multirow{3}{*}{ B } & Shimizu Park & 2007 & spring & male & current-year \\
& & 2007 & spring & male & old \\
\hline & & 2007 & spring & male & current-year \\
& & 2007 & spring & male & old \\
& & 2008 & spring & male & current-year \\
& Forestry and Forest Products & 2008 & spring & male & old \\
C & 2008 & spring & female & old \\
& Research Institute & 2008 & spring & female & old \\
& & 2008 & autumun & male & current-year \\
& & 2008 & autumun & male & old \\
& & 2008 & autumun & female & old \\
\hline
\end{tabular}

これまでカフェ酸誘導体含量の季節変動に関する報告の 例はない。そこで, 苦丁茶の品質の改善に寄与すること を目的に，採取した場所，時期，葉位がそれぞれ異なる と, カフェ酸誘導体がどのように変化するかを調査した。 また, タラヨウは雌雄異株の樹木であるため, 䧳雄の 異なる樹木の葉についてもカフェ酸誘導体の変動を調査 したので報告する。

\section{実験方法}

\section{1. 試 料}

試料のタラヨウは, 東京都文京区の国立大学法人 東 京大学大学院理学系研究科付属植物園 (以下 $\mathrm{A}$ 園), 千 葉県野田市の株式会社 千秋社 清水公園（以下 B 園）, 茨城県つくば市の独立行政法人 森林総合研究所（以下 C 園）で採取した（Table 1)。採取回数は各園で異な るが，2007年および2008年春（5月下旬〜 6 月上旬）と 2008年秋（10月下旬）に採取した。春，秋ともに当年葉 と古葉を採取し, 春の当年葉 (新葉) は先端から数えて 第 3 葉または第 4 葉まで採取し，茥も含めて実験に供し た。タラヨウは成長の遅い樹木であり ${ }^{2)}$, 新葉が出るの は春だけで，茶樹（Camellia sinensis（L) O. Kuntze）の ように夏から秋にかけて新たな新葉が出ることはほとん
どないため，春に出た新葉が成長したものを秋の当年葉 とし，実験には葉だけを使用した。また，古葉は採取し た葉により葉齢が異なるが, 当年葉以外の前年までの葉 はすべて古葉として採取し，葉だけを用いた。雌株では 2008年度の春には新葉が出なかったため古葉のみを採取 した。なお，タラヨウの雌雄の判断は実をつけるものを 雌株とし, それ以外は全て雄株とした。試料は純水で洗 浄したのち凍結乾燥し, 粉末にして実験に供した。

\section{2. 試薬}

5-CQA は MP Biomedicals 製， 3，5-ジーOーカフェ オイルキナ酸（以下 $3,5-\mathrm{CQA}$ ) は ALEXIS Biochemicals 製, カフェ酸はナカライテスク株式会社製を用いた。 その他の試薬は和光純薬工業株式会社の特級または HPLC 用試薬を使用した。

\section{3. 抽出}

抽出は粉末試料 $1 \mathrm{~g}$ に $80 \%$ メ夕ノール溶液 $20 \mathrm{~mL}$ を加 え60分間振盪抽出（MMS-3010, EYELA）し，不溶物を 濾紙（No. 5 A, ADVANTEC）で除去した。滤液は減圧 濃縮し, 濾紙上の残椬には $20 \mathrm{~mL}$ の $80 \%$ \% タール溶 液を加え, 30分間振盪抽出し, 滤紙で滤過し, 滤液を先 


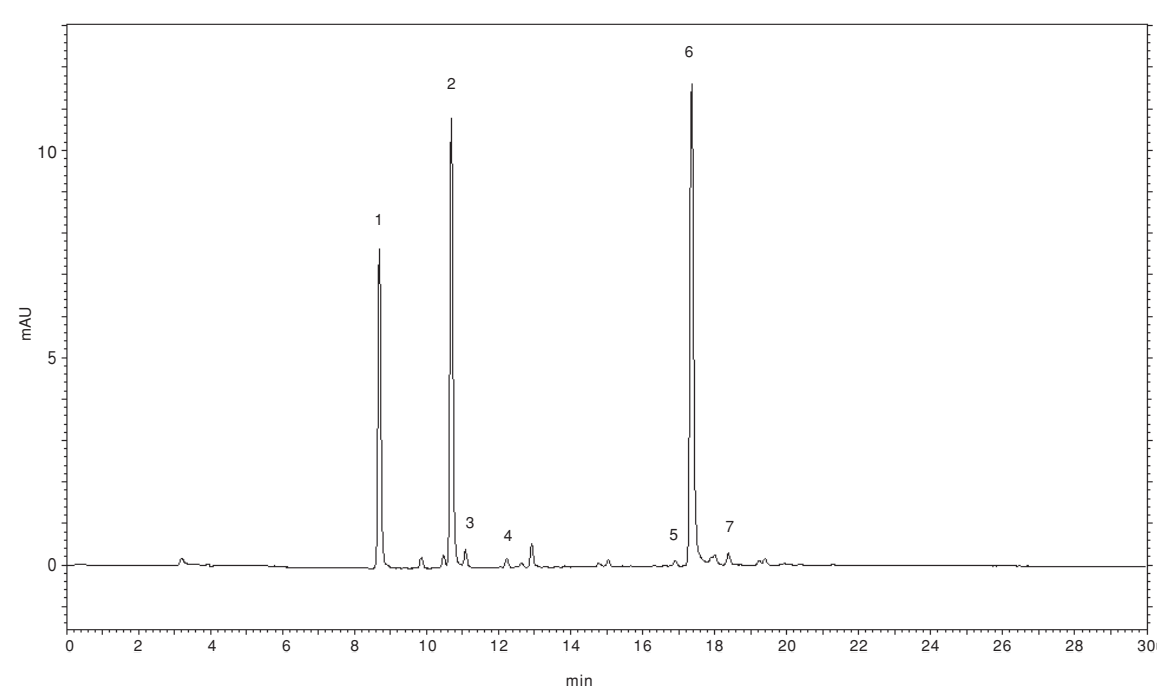

Fig. 2 Separation of several caffeic acid derivatives in Ilex latifolia by HPLC Each peak is 1 ; 3-CQA, 2;5-CQA, 3;4-CQA, 4; caffeic acid, 5; 3,4-CQA, 6; 3,5-CQA and $7 ; 4,5-\mathrm{CQA}$.

の滤液濃縮液と合わせた。この抽出液を減圧下で濃縮し メタノールを除いた後, 凍結乾燥し溶媒抽出試料とした。 タラヨウ凍結乾燥試料は使用時に $5 \%$ ア セトニトリル溶 液を加え定容し，メンブランフィルター（DISMIC25CS, ADVANTEC）で濾過し分析に供した。

\section{4. カフェ酸誘導体の HPLC 測定}

カフェ酸誘導体含量は, 前述の試料溶液を用いて HPLCで測定した。HPLCは株式会社島津製作所製の LC-2010Cを使用し，ガードカラムは XBridge C18 Guard Cartridge $(\phi 4.6 \times 20 \mathrm{~mm}$, Waters $)$, カラムは XBridge C18 Column（ $\phi 4.6 \times 250 \mathrm{~mm}$, Waters）を使用 した。移動相は $1 \%$ ぎ酸（A），アセトニトリル / $1 \%$ ぎ 酸（B）を用い，Aに対して B を30分間で $5 \%$ から $50 \%$ となる濃度勾配で, $40{ }^{\circ} \mathrm{C}$ を保持しながら流速 $0.8 \mathrm{~mL} / \mathrm{min}$ で溶出し，波長 $326 \mathrm{~nm}$ で測定した。今回標品として入 手できたカフェ酸， 5-CQA，3,5-CQA 以外のカフェ オイルキナ酸は, Negishi らの報告 ${ }^{4)}$ に基づき同定した。 これらの定量については，5-CQAの検量線に基づいて モル吸光係数を用いて算出した。

\section{実験結果}

\section{1. モル吸光係数}

5-CQA および 3,5-CQA のメタノール溶液中でのモ ル吸光係数 $(\varepsilon)$ は，それぞれ，18, $400(\lambda$ max $328 \mathrm{~nm})$, $34,600(\lambda \max 329 \mathrm{~nm})$ であった。 Rubach ${ }^{17)}$ はカフェ 酸誘導体 3-CQA, 4-CQA, 5-CQA，3,4-CQA，3,5CQA，および4,5-CQAの $\varepsilon$ をそれぞれ，18,400，18,000, 19, 500，31,800，31，600，33, 200 と報告している。また, Barnes ら ${ }^{18)}$ は95 \%エタノール溶液中での 3 -CQA と 5 CQAの $\varepsilon$ をそれぞれ，18, 900，18,500と報告している。 発色団数が同じ場合モル吸光係数が同じであると仮定し
た場合，誤差は $10 \%$ 以内に留まると考えられることから， 標品を入手できないモノカフェオイルキナ酸は $5-\mathrm{CQA}$ 当量, ジカフェオイルキナ酸は $3,5-\mathrm{CQA}$ 当量で算出 した。

\section{2. 葉中のカフェ酸誘導体含量の変化}

カフエ酸誘導体の吸収極大波長 $328 \mathrm{~nm}$ で夕ラヨウ抽 出物を HPLCで分析した。標準溶液で作成した検量線は, カフェ酸 $0.2 \mu \mathrm{g} / \mathrm{mL} \sim 20 \mu \mathrm{g} / \mathrm{mL}, 5$-CQA $0.3 \mu \mathrm{g} / \mathrm{mL}$ $30 \mu \mathrm{g} / \mathrm{mL}$ の範囲で $\mathrm{r}=0.998$ 以上の良好な直線性を示した。 また, カフェ酸標準溶液 0.2，2.0，20 $\mu \mathrm{g} / \mathrm{mL} ， 5-\mathrm{CQA}$ 標準溶液 $0.3 ， 3.0,30 \mu \mathrm{g} / \mathrm{mL}$ につき 4 回の繰り返し測 定を行ったところ，相対標準偏差はそれぞれ2.7，0.7， $0.4 \% ， 3.3 ， 0.7 ， 0.2 \%$ で，低濃度でやや高かったも のの満足すべき結果であった。さらに， $S / N=3$ とした ときの検出限界はカフェ酸 $0.024 \mu \mathrm{g} / \mathrm{mL}, 5-\mathrm{CQA}$ $0.034 \mu \mathrm{g} / \mathrm{mL}$ であり， $S / N=10$ としたときの定量限界は それぞれ0.078 $\mu \mathrm{g} / \mathrm{mL}, 0.11 \mu \mathrm{g} / \mathrm{mL}$ であった。

A 園で2007年度に採取した春の新葉を用いて添加回収 試験を実施した。カフェ酸を $9.6 \mu \mathrm{g} / \mathrm{g}, 0.8 \mathrm{mg} / \mathrm{g}$, $8 \mathrm{mg} / \mathrm{g}$ 添加した場合の回収率は，それぞれ79, 63, 56 \%だった。相対標準偏差 $(\mathrm{n}=3)$ はそれぞれ2. 3, 10.0, 9.9 \%だった。5-CQA を $13.6 \mu \mathrm{g} / \mathrm{g}, 1.2 \mathrm{mg} / \mathrm{g}, 12 \mathrm{mg} /$ $\mathrm{g}$ 添加した場合の回収率は，それぞれ100，102，86\%で， 相対標準偏差はそれぞれ0.89，6.6，7.5\%だった。力 フェ酸は回収率が低かったが、 5-CQA は回収率, 相対 標準偏差ともに良好な結果が得られた。

分析の結果, 3-CQA $\left(t_{\mathrm{R}}=8.6 \mathrm{~min}\right), 5-\mathrm{CQA}\left(t_{\mathrm{R}}=10\right.$. $7 \mathrm{~min}), \quad 4-\mathrm{CQA}\left(t_{\mathrm{R}}=11.0 \mathrm{~min}\right)$, カフェ酸 $\left(t_{\mathrm{R}}=12.2 \mathrm{~min}\right)$, $3,4-\mathrm{CQA}\left(t_{\mathrm{R}}=16.9 \mathrm{~min}\right), 3,5-\mathrm{CQA}\left(t_{\mathrm{R}}=17.3 \mathrm{~min}\right), 4,5$ $-\mathrm{CQA}\left(t_{\mathrm{R}}=18.3 \mathrm{~min}\right)$ の計 7 種類が検出された（Fig. 2$)$ 。 カフェイン標品は $11.3 \mathrm{~min} に$ 検出されたが, タラヨウ 


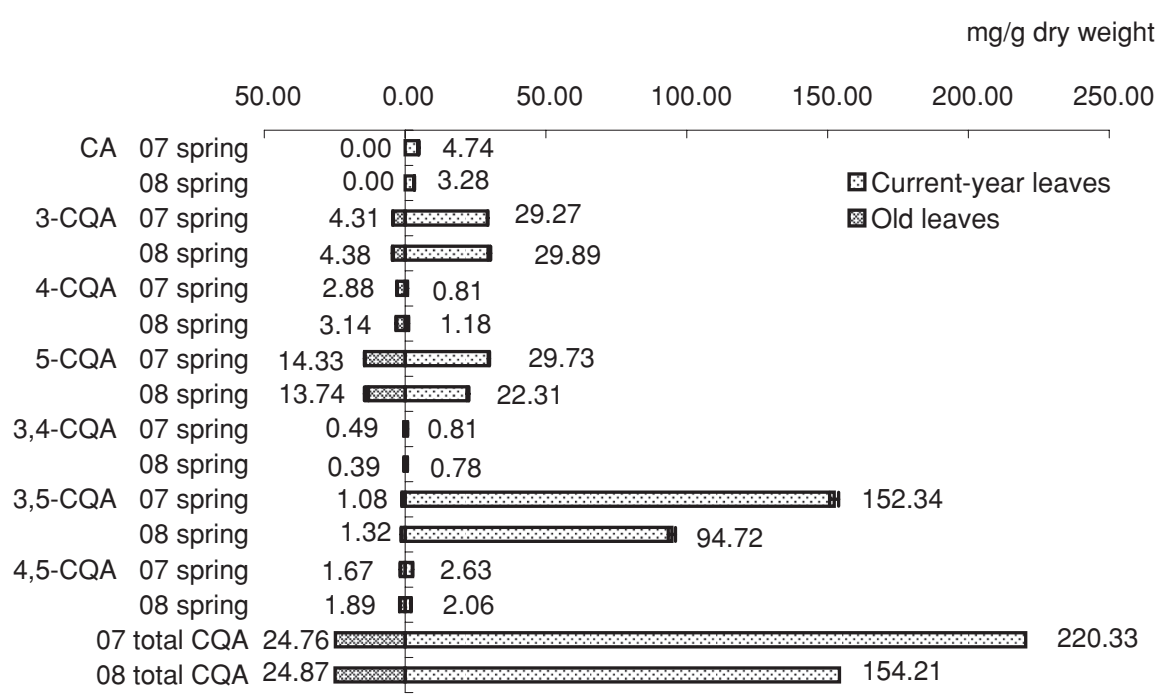

Fig. 3 Changes of caffeic acid derivatives content of Ilex latifolia in park A

Each sample was determined 4 times. Leaves with different leaf age were gathered in the spring of 2007 and 2008. The total CQA matched seven caffeic acid derivatives.

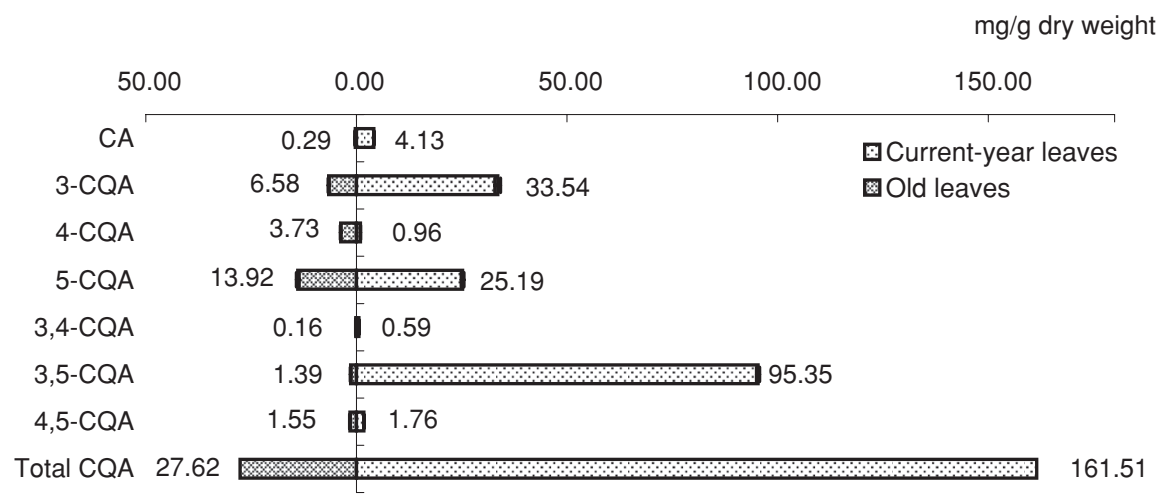

Fig. 4 Changes of caffeic acid derivatives content of Ilex latifolia in park B Each sample was determined 4 times. Leaves with different leaf age were gathered in the spring of 2007. The total CQA matched seven caffeic acid derivatives.

中には確認されなかった。

カフェ酸誘導体含量の測定結果は， A 園を Fig. 3， B 園を Fig. 4, C 園を Fig. 5 に示した。

春に採取した葉を葉位別でみると，カフェ酸誘導体は 当年葉に多量に含まれ，特に3-CQA，5-CQA，3,5CQA が多く，これらに比べてカフェ酸，4-CQA，3，4 -CQA，4,5-CQA は少なかった。最も多かった 3,5一 CQA では, 各採取地の当年葉で 87〜 $156 \mathrm{mg} / \mathrm{g}$ (dry weight）だった。ほとんどのカフェ酸誘導体は古葉で減 少し，当年葉で最も多かった $3,5-\mathrm{CQA} は 0.65 〜 2.03$ $\mathrm{mg} / \mathrm{g}$ (dry weight) になった。カフェ酸誘導体総量でも, 当年葉ではおよそ100 mg～300 mg (dry weight) だった が, 古葉では $20 \mathrm{mg} \sim 50 \mathrm{mg}$ (dry weight) に減少した。 しかし，4-CQA だけが当年葉から古葉への変化で増加 していた。春に採取した葉では，葉位によるカフェ酸誘 導体含量の差が顕著であり，その組成は採取年度が替 わっても変化はないが，葉位が変わると，4-CQAは 3

〜 6 倍増加し, 他は大きく減少していた。 秋の当年葉のカフェ酸誘導体含量は, 春の当年葉に比
べ少量であり古葉との差はなかった。葉の外見も, 春の 当年葉は薄い緑色で柔らかい葉だったが，秋の当年葉は 古葉と同様の濃い緑色で，厚く光沢があり縁に鋸歯をも つ硬い葉に変化していた。採取場所や採取年度により含 量に違いはあるものの, 葉位ごとの含量や組成は同じ変 動を示した。

\section{3. 雌株の葉中カフェ酸誘導体含量の変化}

雌株から採取した古葉中のカフェ酸誘導体含量の季節 変動はFig. 6 に示した。雌株の葉のカフェ酸誘導体総量 は, 春 $46 \mathrm{mg} / \mathrm{g}$ (dry weight), 秋 $35 \mathrm{mg} / \mathrm{g}$ (dry weight) で，春から秋になると減少していたが，組成には大きな 変化はなかった。カフェ酸, ジカフェオイルキナ酸が少 なく，モノカフェオイルキナ酸が多く，その中でも5CQA が最も多かった。雌株の葉中カフェ酸誘導体含量 は雄株の古葉と同等であり，組成も似ていた。

\section{考察} モチノキ属の苦丁茶の重要な成分は, カフェ酸誘導体 


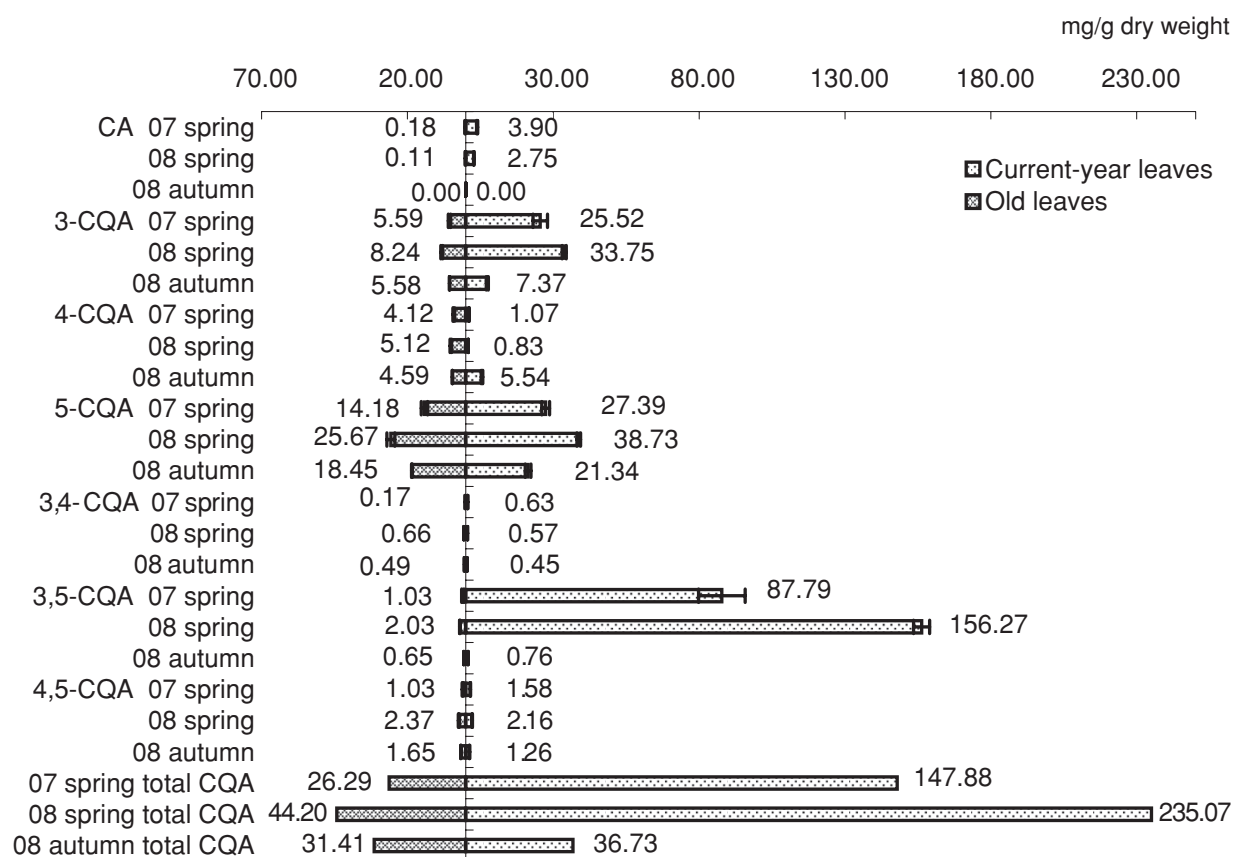

Fig. 5 Changes of caffeic acid derivatives content of Ilex latifolia in park C

Each sample was determined 4 times. Leaves with different leaf age were gathered in the spring of 2007 and 2008 and in autumn of 2008. The total CQA matched seven caffeic acid derivatives.

とサポニンであることが, これまでの研究から明らかに されている。カフェ酸誘導体についてはいくつかの報 告 ${ }^{4)}{ }^{19)}$ 20) があるが, タラヨウ葉中のカフェ酸誘導体を定 量した例は Negishi らの報告 ${ }^{4)}$ のみであり，季節変動や 雌雄の差異についての報告は見あたらない。このような 成分変動の解明は, 苦丁茶の品質の改善に貢献すると思 われる。この目的から本研究を行った結果, 春から秋に かけて当年葉中のカフェ酸誘導体が著しく減少すること, 雌雄では発芽に差があることがわかった。

春に採取したタラヨウの当年葉からは, カフェ酸およ び 6 種類のカフェ酸誘導体が検出された。 3 園とも 3,5 -CQA が最も多く, カフェ酸誘導体総量の平均值は 184 $\mathrm{mg} / \mathrm{g}$ (dry weight) で, 春の当年葉には多量のカフェ 酸誘導体が含まれていた。春の当年葉のカフエ酸誘導体 の分析結果は, Negishi ら ${ }^{4)}$ が苦丁茶原料のひとつとし て定量したタラヨウの分析結果とほぼ一致していた。し かし, 春から秋にかけて当年葉のカフェ酸誘導体は顕著 に減少しており，また，前年までに展開した葉である古 葉では, カフェ酸誘導体総量が春の当年葉の $1 / 5$ 以下 に減少していた。6 種類のカフェ酸誘導体の中で, 4$\mathrm{CQA}$ のが秋の当年葉や古葉で春の当年葉より多かっ た。すなわち，葉の成長・老化とともに，4-CQA 以外 のカフェ酸誘導体が減少し, その総量も減ることがわ かった。

各種の植物が, 様々な抗酸化成分を持つことは広く知 られている。ポリフェノールはその代表的な化合物群で あり, クロロゲン酸などのカフェ酸誘導体は, シュンギ ク，ゴボウなどのキク科植物やサッマイモ，コーヒーに 多く含まれる ${ }^{21)}$ 25)。またカテキンは, 茶の抗酸化成分
として知られている。茶樹はタラヨウと異なり, 年に何 度も新芽を出す樹木で, カテキン類は茶芽の小さい時期 に多く, 成長と共に減少するが, 春に出芽した葉を摘み 取る 1 番茶より, 夏に出た葉を採取する 2,3 番茶に多 く，その後秋に向かって減少していくことが報告されて

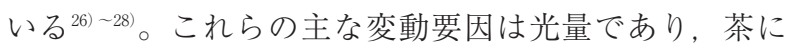
含まれるカテキン類は露光下で増加し, 遮光下で低下す ることがわかっている。光によるカテキン生合成の調節 は, フェニルアラニンアンモニアリアーゼ (PAL) の活 性低下によるところが大きく, この酵素活性は茶樹を被 覆すると急減する ${ }^{29)}$ 。

Zucker $^{30)}$ は, サッマイモ塊茎組織において PAL 活性 は光により刺激を受け, クロロゲン酸合成の速度は PAL 活性に比例すると報告しており, クロロゲン酸の増減も カテキンと同様に，PAL 活性が紫外線量により変化す るためと考察している。したがって, タラヨウのカフェ 酸誘導体は, 紫外線量の多い夏にはさらに増加すると考 えられる。

前述のように, 6 種類のカフェ酸誘導体の中で 4CQA は, 他の化合物と異なる変動であり, 春は古葉の 含量が当年葉より高く, 秋の当年葉では春の当年葉の含 量を上回っていた。Padda ら ${ }^{31}$ は, サッマイモ葉中のカ フェ酸誘導体変動を調査し, クロロゲン酸, カフェ酸, ジカフェオイルキナ酸は葉の成長と共に減少することを 報告しているが，4-CQA は未測定である。Tomas-Barberan ${ }^{32}$ 33) は, レタスに傷をつけると傷害応答が起こり， PAL が誘導されポリフェノールが徐々に合成された後 に酵素的褐変が起きると報告している。その際に合成さ れるポリフェノールは主にカフェオイルキナ酸で, 代謝 


\begin{tabular}{|c|c|c|c|c|c|c|}
\hline & & & & & & weight \\
\hline 50.00 & 30.00 & & 0.00 & & 30.00 & 50.00 \\
\hline $\mathrm{CA}$ & & & 0.150 .44 & & & \\
\hline 3-CQA & & 6.19 & 1 & 8.00 & 08 at & leaves \\
\hline 4-CQA & & 5.27 & ए & 5.53 & & \\
\hline 5-CQA & 19.63 & 12: & 28 & 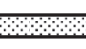 & (1) 26.2 & \\
\hline 3,4-CQA & & & 0.390 .59 & & & \\
\hline 3,5-CQA & & & 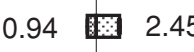 & & & \\
\hline 4,5-CQA & & & 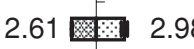 & & & \\
\hline Total CQA & 35.18 & & 5 & & & 46.23 \\
\hline
\end{tabular}

Fig. 6 Changes of caffeic acid derivative contents in female plant leaves in Ilex latifolia Each sample was determined 4 times. Leaves were gathered in the spring of 2008 and in autumn of 2008. The total CQA matched seven caffeic acid derivatives.

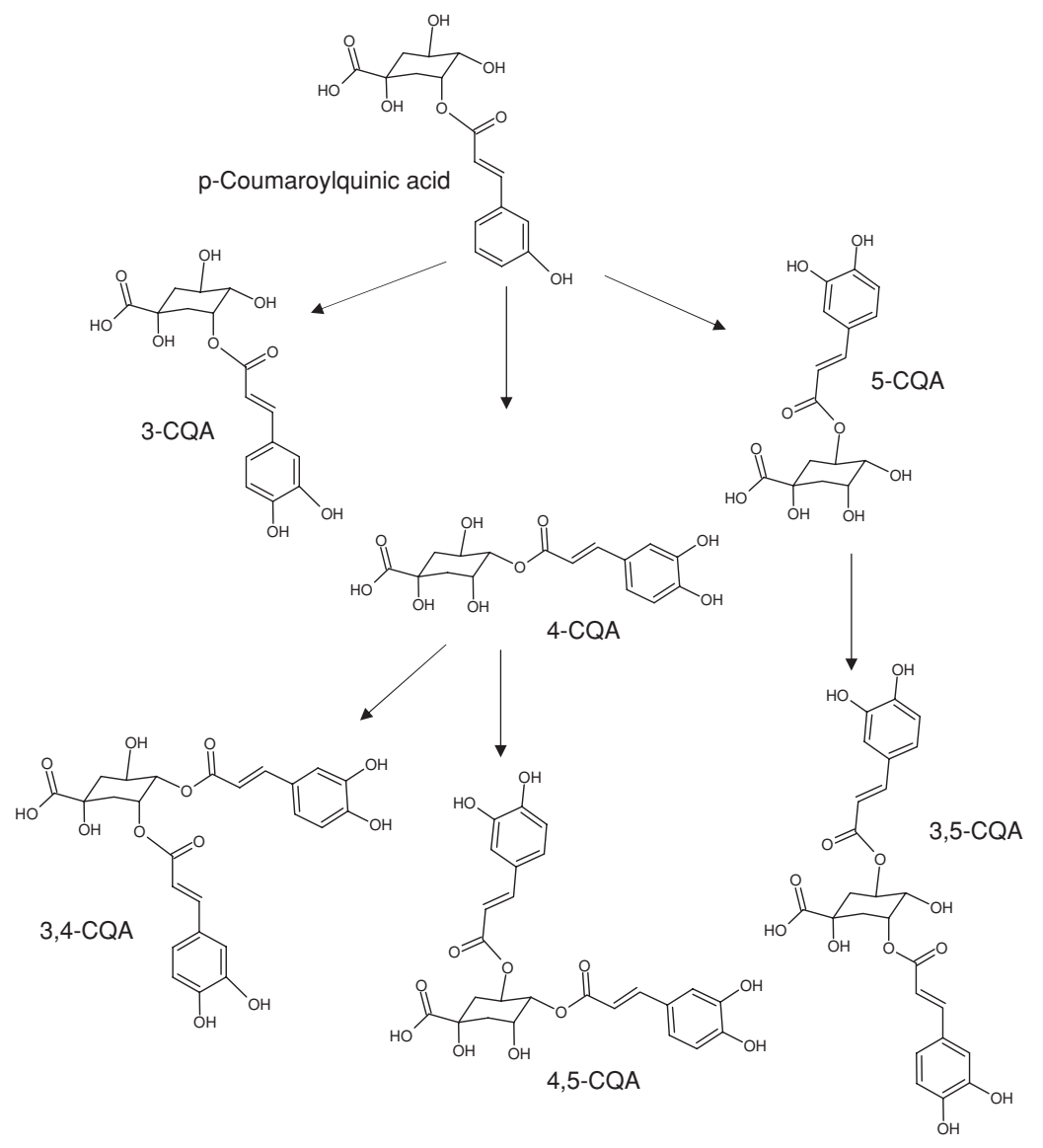

Fig. 7 Expected metabolic pathway of caffeic acid derivatives in Ilex latifolia

経路の中で 4-CQA から 3,4-CQA と 4,5-CQA が合 成され，5-CQA から 3,5-CQA が合成されると示して いる。タラヨウについても, レタスと同じ代謝経路が存 在し, 3,4-CQA と 4,5-CQAの 2つのジカフェオイ ルキナ酸は，4-CQA から合成されていると考えられる (Fig. 7)。春季より秋季に 4-CQA の濃度が高い点につ いては，秋季になっても $\mathrm{p}$-クマロイルキナ酸から 4CQAへの合成が衰えないにもかかわらず，4-CQA から， 3,4-CQA および 4,5-CQAへの代謝が不活発になっ たことが原因と推察される。
茶と苦丁茶は，ともに古くから健康維持機能があると されている飲料であり，それぞれ抗酸化成分であるカテ キンとカフェ酸誘導体を多量に含む。またカテキンもカ フェ酸誘導体も苦味を呈する。茶の浸出液中に最も多い 成分はカテキンであるが, 苦丁茶の浸出液中の成分組成 は，原料植物が 10 種もあることから不明な部分が多い。 我々が行った中国市販苦丁茶中のミネラルおよび遊離ア ミノ酸含量の定量 ${ }^{34)}$ では, ミネラル含量は茶と大きな差 はなく，組成も同様の傾向であり，遊離アミノ酸は茶に 比べて少量であることを確認している。苦丁茶中のサポ 
ニンについては定量の報告はなく, カフェ酸誘導体につ

いても浸出液中含量に関する報告はない。

茶は抗酸化成分以外にも, その品質に欠かせない成分 がある。そのひとつがアミノ酸であり，含量は 1 番茶に 最も多く， 2 番茶 3 番茶と減少していくことがわかって いる ${ }^{28)}$ 。しかし, 苦丁茶のアミノ酸は前述の通り少量で あり, アミノ酸による味への寄与はきわめて少ないと考 察される。

カフェインも, 茶の品質や効能に関わる成分である。 カフェインは茶だけでなく, コーヒー, ココア, マテ茶 など多くの嗜好飲料中に存在するが, 本研究の中では,

カフェインを検出した試料はなかった。マテ茶の原料で あるマテはカフェインを含有するが, 同属であるタラヨ ウはカフェインを含まないことになる。

タラヨウの春の当年葉は, 抗酸化活性があるカフェ酸 誘導体を多量に含む。植物中のポリフェノールは水抽出 において，温度が高いほど抽出効率が良いとされている ため ${ }^{35)}{ }^{36)}$ ，茶として飲用することは，抗酸化成分を効率 良く摂取することになる。タラヨウは萌芽力のそしい樹 木であるため ${ }^{2)}$, 雌株では果実への転流により新葉が出 ない場合がある。したがって，より安定した苦丁茶の生 産のためには, 芽の休眠が起こりにくい雄株の新葉が適 している。しかし, カフェ酸誘導体は，未変化体のまま では吸収されにくく37) -39)，体内に吸収されると速やか にカフェ酸とキナ酸に分解され，血中ではフェルラ酸の ようなカフェ酸代謝物として存在すると報告されてい る ${ }^{40)}{ }^{41}$ 。今後は, タラヨウ製茶品を熱水抽出して飲用し た後のカフェ酸誘導体の体内における動態についても研 究を行い, 飲料の効能をさらに検討する必要がある。

\section{謝 辞}

タラヨウについて御提供，御助言いただきました国立 大学法人東京大学大学院理学系研究科付属植物園, 株 式会社 千秋社 清水公園, 独立行政法人 森林総合研究所 企画部 研究管理科 実験林室長 吉武孝博士, 元実験林室 金指達郎氏に御礼申し上げます。

\section{文 献}

1) 岩柣邦男, 大場秀章, 清水建美, 堀田満, ギリアン・プ ランス, ピーター・レーヴン：週刊朝日百科 植物の世界,

種子植物 - 双子葉類 4 , 朝日新聞社, 東京, p72 79（1997）

2 ) 林弥栄, 古里和夫, 中村恒雄: 原色樹木大圖鑑, 北隆館, 東京, p454（1987）

3 ）横澤隆子, 野中源一郎：苦丁茶を探る, FOOD Style 21, 7, 77-80 (2003)

4) Negishi, O., Negishi, Y., Yamaguchi, F. and Sugahara, T.: Deodorization with Ku-ding-cha containing a large amount of caffeoyl quinic acid derivatives. J. Agric. Food Chem., 52, 5513-5518 (2004)

5 ) Ouyang, M.A., Wang, H.Q., Liu, Y.Q., and Yang, C.R.: Triterpenoid saponins from the leaves of Ilex latifolia. Phytochemistry, 45, 1501-1505 (1997)
6 ) Ouyang, M.A., Liu, Y.Q., Wang, H.Q. and Yang, C.R.: Triterpenoid saponins from Ilex latifolia. Phytochemistry, 49, 24832486 (1998)

7 ) Huang, J., Wang, X., Ogihara, Y., Shimizu, N., Takeda, T. and Akiyama, T.: Latifolosides I and J, two new triterpenoid saponins from the bark of Ilex latifolia. CHEMICAL \& PHARMACEUTICAL BULLETIN, 49, 239-241 (2001)

8 ) Huang, J., Wang, X., Ogihara, Y., Shimizu, N., Akiyama, T. and Takeda, T.: Latifolosides $\mathrm{K}$ and L, two new triterpenoid saponins from the bark of Ilex latifolia. CHEMICAL \& PHARMACEUTICAL BULLETIN, 49, 765-767 (2001)

9 ) Yoshimoto, M., Yahara, S., Okuno, S., Islam, S. M., Ishiguro, K. and Yamakawa, O.: Antimutagenicity of mono-, di-, and tricaffeoylquinic acid derivatives isolated from Sweetpotato (Ipomoea batatas L.) leaf. Biosci. Biotech. Biochem., 66, 2336 -2341 (2002)

10) Kurata, R., Adachi, M., Yamakawa, O. and Yoshimoto, M.: Growth suppression of human cancer cells by polyphenolics from sweetpotato (Ipomoea batatas L.) leaves. J. Agric. Food Chem., 55, 185-190 (2007)

11）鍔田仁人, 高垣欣也, 吉本誠, 倉田理恵, 山川理 : 甘藷 若葉末の血糖改善効果，食品と開発，39，57-58（2007）

12) Bravo, L., Goya, L. and Lecumberri, E.: LC/MS characterization of phenolic constituents of mate (Ilex paraguariensis, St. Hil.) and its antioxidant activity compared to commonly consumed beverages. Food Research International, 40, 393405 (2007)

13) Heck, C.I. and De Mejia, E.G.: Yerba Mate Tea (Ilex paraguariensis) : a comprehensive review on chemistry, health implications, and technological considerations. J. Food Sci., 72, R138-151 (2007)

14) Lunceford, N., Gugliucci, A.: Ilex paraguariensis extracts inhibit AGE formation more efficiently than green tea. Fitoterapia, 76, 419-427 (2005)

15) Chandra, S. and De Mejia, E.G.: Polyphenolic compounds, antioxidant capacity, and quinone reductase activity of an aqueous extract of Ardisia compressa in comparison to mate (Ilex paraguariensis) and green (Camellia sinensis) teas. J. Agric. Food Chem., 52, 3583-3589 (2004)

16) Liang, Y., Ma, W., Lu, J. and Wu, Y.: Comparison of chemical compositions of Ilex latifolia Thumb and Camellia sinensis L., Food Chemistry, 75, 339-343 (2001)

17) Rubach, K.: Dissertation, Technische Universität Berlin, German (1969)

18) Barnes, H.M., Feldman, J. R. and White, W. V.: Isochlorogenic acid. Isolation from coffee and structure studies. J. Am. Chem. Soc., 72, 4178-4182 (1950)

19) Wang, Z., Clifford, M. N. and Sharp P.: Analysis of chlorogenic acids in beverages prepared from Chinese health foods and investigation, in vitro, of effects on glucose absorption in cultured Caco- 2 cells. Food Chemistry, 108, 369-373, (2008)

20) Liu, L. , Sun, Y., Laura,T., Liang, X., Ye, H. and Zeng, X.: Determination of polyphenolic content and antioxidant activity of kudingcha made from Ilex kudingcha C.J. Tseng. Food Chemistry, 112, 35-41 (2009)

21) Chuda, Y., Ono, H., Ohnishi Kameyama, M., Nagata, T., Tsushida, T.: Structural identification of two antioxidant quinic acid derivatives from garland Chrysanthemum coronarium 
L.) . J. Agric. Food Chem., 44, 2037-2039 (1996)

22）王蓉, 綾野秀志, 古本敏夫, 近藤昭, 福井宏至: ゴボウ 中のクロロゲン酸関連成分含量の品種間差異, 食科工, 48 , 857-862 (2001)

23) Maruta, Y., Kawabata, J. and Niki, R.: Antioxidative caffeoylquinic acid derivatives in the roots of burdock (Arctium lappa L.）. J. Agric. Food Chem., 43, 2592-2595（1995）

24) Takenaka, M., Nanayama, K., Isobe, S. and Murata, M.: Changes in Caffeic Acid Derivatives in Sweet Potato (Ipomoea batatas L.) during Cooking and Processing. Biosci. Biotech. Biochem., 70, 172-17 (2006)

25) Faraha, A., Monteiro, M.C., Calado, V., Franca, A.S. and Trugo, L.C.: Correlation between cup quality and chemical at tributes of Brazilian coffee. Food Chemistry, 98, 373-380 (2006)

26）森田明雄, 小西茂毅, 中村順行, 清水絹恵, 横田博実 : チャ 品種の育成年度に応じた茶葉中の各種成分含量の変化, 育 種学研究, 6, 1-9 (2004)

27）田中伸三, 岩浅潔, 深津修一, 青野英也, 田中静夫, 佐 波哲次: 茶葉の摘採時期と製茶品質との関係, 野菜・茶業 試験場報告 B (金谷)，3，55-64（1989）

28）近藤知義, 仲上和博, 和田義彦, 今村嘉博, 志和将一 : カテキン類利用原料としての夏秋茶の摘採時期と位置, 滋 賀県農業技術振興センター研究報告，46，36-44（2007）

29）村松敬一郎: 茶の科学, 朝倉書店, 東京, p38-42（1991）

30) Zucker, M.: Induction of Phenylalanine Deaminase by Light and its Relation to Chlorogenic Acid Synthesis in Potato Tuber Tissue. Plant Physiol., 40, 779-784 (1965)

31) Padda, M. S. and Picha, D. H.: Antioxidant Activity and Phenolic Composition in 'Beauregard' Sweetpotato Are Affected by Root Size and Leaf Age. J. Am. Soc. Hort. Sci., 132, 447451 (2007)

32) Lopez-Galvez, G., Saltveit, M. and Cantwell, M.: Wound-induced phenylalanine ammonia lyase activity: factors affecting its induction and correlation with the quality of minimally processed lettuces. Postharvest Biology and Technology, 9 , 223-233 (1996)

33) Tomas-Barberan, F. A., Loaiza-Velarde, J., Bonfanti, A. and Saltveit, M.E.: Early Wound- and Ethylene-induced Changes in Phenylpropanoid Metabolism in Harvested Lettuce. J. Am. Soc. Hort. Sci., 122, 399-404（1997）

34）翠川美穂，藤原しのぶ，佐々木弘子：苦丁茶の遊離アミ ノ酸組成, ミネラル含量, 総ポリフェノール含量と官能評価, 日本食生活学会誌, 20, 134-142（2009）

35）鶴永陽子, 松本敏一, 富川康之, 板村裕之: 採取時期お よび雌雄がヤマモモの当年葉に打けるラジカル捕捉活性に 及ぼす影響, 園芸学研究, 6，151-156（2007）

36）柚木崎千鶴子, 小村美穂, 小坂妙子, 堂園眞澄: 乾燥温 度及び抽出法の違いによるハーブ類の抗酸化活性, 宮崎県 工業技術センター・宮崎県食品開発センター研究報告, 49 , 69-75 (2004)

37) Azuma, K., lppoushi, K., Nakayama, M., Ito, H., Higashio, H. and Terao, J.: Absorption of Chlorogenic Acid and Caffeic Acid in Rats after Oral Administration. J. Agric. Food Chem., 48, 5496-5500 (2000)

38) Takenaka, M., Nagata, T. and Yoshida, M.: Stability and Bioavailability of Antioxidants in Garland (Chrysanthemum coronarium L.). Biosci. Biotech. Biochem., 64, 2689-2691 (2000)

39) Olthof, R.M., Hollman, C. H. P. and Katan, B.M.: Chlorogenic acid and caffeic acid are absorbed in humans. J. Nutr., 131, 66-71 (2001)

40) Gonthier, M.P., Verny, M.A., Besson, C., Rémésy, C. and Scalbert, A.: Chlorogenic acid bioavailability largely depends on its metabolism by the gut microflora in rats. J. Nutr., 133, 1853-1859 (2003)

41) Wittmer, S.M., Ploch, M., Windeck, T., Müller, S.C., Drewelow, B., Derendorf, H. and Veit, M.: Bioavailability and pharmacokinetics of caffeoylquinic acids and flavonoids after oral administration of Artichoke leaf extracts in humans. Phytomedicine, 12, 28-38 (2005) 